\title{
IMPLEMENTATION OF THE SPECIAL COURSE "BASES OF MEDIA EDUCATION IN THE PRIMARY SCHOOL" IN THE PROFESSIONAL TRAINING OF FUTURE TEACHERS
}

\section{Tolmachova Iryna ${ }^{1}$}

DOI: https://doi.org/10.30525/978-9934-571-89-3_24

The education of the younger generation in institutions of general secondary education is based exclusively on the systematic use of media that enables the effectiveness and efficiency of the educational process, opens up prospects for indepth study of disciplines, and provides opportunities for educators to be in the trend of modern realities that are associated with the development of media-funds. Undeniably, using gadgets as learning tools, teachers are innovators, mentors and managers of the educational process, targeting modern youth to work with media products, isolating important information from a large stream of media texts, and solving education tasks with media. In order to achieve such learning outcomes in today's realities, in particular, to teach students competently and professionally to acquire knowledge through phones, tablets, laptops, the teacher should be a modern, innovative specialist. That is why the professional training in higher education institutions should be aimed to a comprehensive study of the basics of media education, the ability to work with media and create media for further use in primary

\footnotetext{
${ }^{1}$ State Institution "Lugansk Taras Shevchenko National University", Ukraine
} 
education [1]. For this purpose, it is worth creating appropriate pedagogical conditions, introducing additional special courses for quality training of future primary school teachers. Thus, the purpose of our intelligence is to characterize the content and structure of the author's special course "Bases of media education in the primary school", which was implemented in institutions of higher education for the formation of media competence of future teachers of elementary school.

For this purpose, at the formative stage of experimental research, we have developed a special course "Bases of media education in the primary school", which is intended for students of the field of knowledge 01 Education/Pedagogy of the specialty "Primary education"; "Primary education. Ukrainian language and literature". Special course is designed for 3 year students, total hours - 90 (3 credits ECTS). The purpose of the special course is to: find out the role of media in the educational process of elementary school; to teach students to use different computer software to create author's media products; to interest future teachers in solving educational problems with media.

The structure of the special course consists of two modules, the topics of which included theoretical mastery of material and the acquisition of the necessary practical skills. In particular, in the first module students had an opportunity to get acquainted with the problem of the formation of media education in Ukraine and abroad; types of media, to determine the role and place of media in the primary school educational process; mastered the basics of media etiquette while working on the Internet. An interesting task for future teachers in studying the indicated themes was the following: compare the definition of "media education" on various information sites; comment on the thesis and substantiate their own opinion, for example, "Do you agree with the fact that the time will come when students do not write, read books, and all means of training will replace media?"; give examples of pedagogical situations, the solution of which involves the use of media.

During the course by performing such tasks, students learned to defend their own point of view, creatively approached the tasks, simulated training situations, involving the use of media. In addition, future teachers were given the opportunity to follow the development stages of the media and to make sure that modern media are intended to refute and facilitate the educational process in elementary school, make it more interesting and diverse, and motivate students to fully master the subject.

The tasks of the first module are aimed to familiarizing future teachers with the trends of perspective introduction of media into the educational process of the elementary school; the formation of critical thinking, the ability to characterize the educational capabilities of media in primary school and determine the rules of conducting in the Internet. We believe that only the systematic use of media in the process of professional training will be a guarantee for the formation of a high level of media competence for future teachers of elementary school.

Equally interesting and important were the tasks of the second module "Using media in primary school", which included acquaintance with computer software, the formation of the ability to visualize information and determine the means of its representation, to create author media products and lessons for the purposes of mediaization. 
Within the second module students worked with computer programs, performed tasks of varying complexity and learned to display and apply theoretical knowledge during practice. So, from the topic "Text Information. Working with Microsoft Word", future teachers improved their Microsoft Word skills, studied the basics of editing and sending text documents through their email address. During these operations, students gained practical skills and work skills in the program, learned to plan the educational process using the specified program; determined the educational potential of Microsoft Word.

Useful and relevant for future professional activities have become themes aimed at studying cloud technology training. First, the students learned about various Google services; secondly, they analyzed the didactic possibilities of cloud technologies; thirdly, during the practical work, we identified the role of Google services in the elementary school education process.

According to O. Palamarchuk, cloud technology training accelerates the process of mastering learning information, facilitates the operational exchange and processing of information, facilitates the interaction and communication of Internet users [2]. In order to automate the actions of users to quickly and efficiently use the potential of electronic services, it is necessary to systematically work with them. Thus, within the framework of the special course, future teachers joined a number of tasks that contributed to the qualitative acquisition of cloud applications, in particular, to create an online survey using cloud technologies, to develop a presentation with the help of Google applications on the topic: "Media in education: Benefits and didactic Significance", prepare a report in a Word document with screenshots describing the step-by-step creation of presentations using cloud-based technologies.

While working with Internet services students formed the desire to be a modern specialist in the pedagogical profession, competently possess the technologies that cyberspace offers. In addition, future teachers were convinced that a lesson learned with the use of Google services would interest educators in studying disciplines, and would encourage students to be in the trend of innovation, which is so important for the information generation of the 21 st century.

Useful for future teachers became topics that actualized the ways of visualizing various types of information, means of its representation. Students visualized the material in Microsoft PowerPoint, Publisher, highlighting the differences between these programs and describing their benefits. During practical tasks, students realized the need for a professional representation of learning information, which would be a guarantee of successful mastery of the material. By working in different programs, students learned to distinguish important information from a large number of media texts, to clearly structure the findings and be able to find ways to represent the materials. To sum up, future teachers actively used an interactive whiteboard aimed at developing student creativity, increasing motivation for further pedagogical activity in the informational space. In addition, the interactive whiteboard simultaneously combines several materials at once: image, sound, video, Internet resources and other materials. The use of interactive devices in the course of professional training motivates future teachers to tailor non-standard approaches to planning the educational process, taking into account the trend learning tools [3]. 
The final segment of the special course was the modeling of a media lesson in elementary school using modern approaches and technologies for teaching younger students. Interesting in this aspect was that future teachers used the whole arsenal of forms, methods, approaches, implementation of which involves the use of a wide range of media and Internet technologies offered by modern cyberspace.

Thus, the introduction and implementation of a special course in the framework of the professional training of future teachers contributed to the formation of a specialist with the scientific base of modern technology education, the success and effectiveness of which depends on the knowledge and skills of future teachers to use media tools for solving professional problems; the interest of students to be in the trend of topical information innovations, the desire to improve and be an interesting teacher for the younger generation of the XXI century. In addition, students learned how to work with media tools, find the best ways to visualize and represent data; to model media lessons using copyrighted media products; to focus attention on the potential of Internet services as an optimal solution to educational problems. Consequently, the special course positively influenced the development of the individual qualities necessary for the teacher of the present day and contributed to the formation of media competence of future teachers of elementary school.

\section{References:}

1. Ivanova L. A. The problem of forming the media competence of the future teacher is ripe and requires discussion / L. A. Ivanov // Magister Dixit. - 2011. - No. 1. - P. 57-71.

2. Palamarchuk A. S. Using cloud service OneDrive in the educational process of the university // Physics and Mathematics Education : scientific journal. - 2016. - Issue 2(8). - P. 87-92.

3. Dniprovskaya N. V. The conceptual foundations of the concept of smart education / N. V. Dniprovskaya, E. A. Yankovskaya, I. V. Shevtsova // Open education. - 2015. - No. 6. P. 43-51. 